\title{
Entre la lucha ideológica y la unidad de acción en las fábricas. La relación del Partido Revolucionario de los Trabajadores con la Tendencia Revolucionaria del Peronismo en los años $70^{*}$
}

\author{
Between the ideological fight and the unity of actions in factories. The \\ relationship of the Worker's Revolutionary Party with the Peronism's \\ Revolutionary Tendency in the 70s
}

\author{
Santiago Stavale ${ }^{* *}$
}

Resumen: En el siguiente trabajo se abordan los debates y las polémicas que sostuvo el Partido Revolucionario de los Trabajadores-Ejército Revolucionario del Pueblo (PRT-ERP) con la llamada "Tendencia Revolucionaria" del peronismo en el marco de la apertura democrática concretada en 1973 y clausurada en marzo de 1976. Al mismo tiempo se analiza la forma en que se tradujo dicha discusión al interior de las fábricas y el tipo de relación que sostuvieron sus militantes en las mismas.

Palabras claves: PRT-ERP, peronismo, fábrica, clase obrera

\begin{abstract}
Controversies and debates held by the Worker's Revolutionary Party People's Revolutionary Army (PRT - ERP) with the so called Revolutionary Tendency of the peronism within the background of the democratic opening in 1973 which was in March 1976 are undertaken in the following paper. At the same time, the way in which such discussions as well as the type of relationship held by the activists inside the factories are also analysed.
\end{abstract}

Keywords: PRT-ERP, peronism, factory, working class.

Recibido: $16 / 01 / 2017$

Aceptado: 24/05/2017

\footnotetext{
* Una versión preliminar ha sido presentada en las XI Jornadas de Sociología de la Universidad Nacional de Buenos Aires, en Julio de 2015

*** Argentino, Licenciado en Sociología por la Universidad Nacional de La Plata. Integrante del proyecto de investigación "Aportes para repensar la trayectoria de la "nueva izquierda" (1955-1976): estrategias, rupturas y reagrupamientos" radicado en la Facultad de Humanidades y Ciencias de la Educación de la Universidad Nacional de La Plata - Argentina y dirigido por la Dra. María Cristina Tortti, en el Centro de Investigaciones Socio Históricas (CISH), Becario doctoral del Consejo Nacional de Investigaciones en Científicas y Técnicas (CONICET), santiagostavale @ gmail.com
} 


\section{Presentación}

La década de 1970 en Argentina fue el período de mayor auge de la lucha de clases de dicho país, en el que la cuestión de qué hacer con el peronismo fue un problema no solo para las clases dominantes sino también para las organizaciones revolucionarias, entre las cuales se encontraba el Partido Revolucionario de los Trabajadores-Ejército Revolucionario del Pueblo (PRT-ERP) ${ }^{1}$.

El golpe militar que derrocó a Perón en 1955 dio inicio a un período de resistencia y radicalización de las luchas obreras que creó las condiciones para una lenta y progresiva contradicción de la alianza policlasista representada por el peronismo ${ }^{2}$. Esto produjo lo que llamamos un proceso de "proletarización del peronismo" que motivó un profundo debate en el seno de las organizaciones de izquierda. El nuevo escenario dio pie para una revisión del fenómeno peronista que llevó a un copioso sector de la intelectualidad y de la militancia izquierdista a romper con las interpretaciones clásicas que lo veían como una mera forma de "totalitarismo", "demagogia" o "manipulación", buscando nuevas interpretaciones que dieran explicación a las razones por las cuales los trabajadores asumían dicha identidad como propia ${ }^{3}$.

Ahora bien, más allá de esta primera ruptura, las interpretaciones del peronismo estuvieron lejos de ser homogéneas en las organizaciones que formaron la "nueva izquierda"4: mientras unos consideraban a Perón como un líder del Tercer Mundo, otros, como el PRT-ERP, "se mantenían críticos respecto de su papel pues lo consideraban un 'líder burgués"', 5

El giro que había dado la lucha de clases con la insurrección obrero-estudiantil conocida como "Cordobazo", en 1969, alentó los debates sobre el carácter y la estrategia que debía tener la revolución en Argentina. Éstos se desarrollaban en torno a dos ejes centrales: por un lado, la discusión sobre la estrategia armada unía al PRT-ERP con organizaciones de la Tendencia Revolucionaria Peronista (TRP) como Montoneros y FAR frente a aquellas que sostenía la estrategia insurreccionalista (Partido Socialista de los Trabajadores -PST-, Política Obrera -PO-, el Partido Comunista Revolucionario -PCR- y

\footnotetext{
${ }^{1}$ Pablo Pozzi, Por las sendas argentinas... El PRT-ERP. La guerrilla Marxista, Buenos Aires, Eudeba, 2001.; Guillermo Caviasca, Dos caminos. ERP-Montoneros en los setenta., Argentina Ediciones del CCC, 2006.; Luis Mattini, Hombres y mujeres del PRT-ERP de Tucumán a la Tablada, La Plata, De la Campana, 4 Edición, 2003.; Daniel De Santis, La historia del PRT-ERP por sus protagonistas, Buenos Aires, A formar filas, editora guevarista, 2010.

2 Pablo Bonavena, Mariana Maañon, Gloria Morelli, Fabián Nievas, Roberto Piva y Martín Pascual, Orígenes y Desarrollo de la Guerra Civil en la Argentina. 1966-1976., Buenos Aires, Eudeba, 1998.

${ }^{3}$ María Cristina Tortti, "La nueva izquierda argentina. La cuestión del peronismo y el tema de la revolución.", María Cristina Tortti (Directora), Mauricio Chama y Adrián Celentano (co-directores), La nueva izquierda argentina (19551976): socialismo, peronismo y revolución., Rosario, Prehistoria Ediciones, 2014.

${ }^{4}$ Utilizamos el concepto de "nueva izquierda" para denominar al conjunto de fuerzas sociales y políticas que durante los años 60 y 70 protagonizaron un proceso de movilización y radicalización política, que incluyeron desde un sinnúmero de grupos intelectuales y culturales hasta los movimientos urbanos de tipo insurreccionales, las direcciones clasistas que surgieron en el movimiento obrero y las organizaciones revolucionarias que optaron por la lucha armada. Estas últimas fueron su manifestación más destacada, y una clara expresión del espíritu de la época, marcado por la revolución cubana y la ruptura con la izquierda tradicional encarnada en la Argentina por los partidos Comunista y Socialista respectivamente. (Idem.)

${ }^{5}$ Ibid., 27
} 
Vanguardia Comunista-VC-). Por el otro, la controversia sobre el papel que debía jugar el peronismo y Perón en esa revolución dividía aguas entre las primeras, reordenando de distinta manera las veredas del debate.

Estas diferencias se profundizaron ante la propuesta del Gran Acuerdo Nacional (GAN), estrategia pergeñada por la cúpula militar, que suponía la convocatoria a elecciones, el regreso a las instituciones democráticas y la legalización del peronismo. La audacia de la maniobra radicaba en proyectar la reinserción del peronismo al sistema político con el objetivo de aislar a los elementos más radicalizados, devolverle legitimidad a la acción estatal y encauzar la conflictividad en el marco de la democracia parlamentaria, frustrando la confluencia entre la izquierda social y la izquierda política ${ }^{6}$. Es por ello que el año 1973 se transformó en un punto de inflexión.

Como remarca Juan Carlos Torre, el retorno de Perón venía de la mano de una reconstrucción política, con un llamado a la conciliación y al "orden social" que tenía una acogida más feliz entre sus adversarios políticos que entre sus propios seguidores. Este plan se encontraba con un primer obstáculo: el hiato existente entre la fórmula de conciliación propuesta por el líder y el espíritu de movilización generalizada ${ }^{7}$.

De este modo la apertura democrática y el triunfo del peronismo en las elecciones de ese año fueron elementos que agudizaron la polémica en la nueva izquierda, obligando a las organizaciones a tomar una posición ante el nuevo gobierno. Apoyarlo podía significar estar del lado del pueblo y de la revolución o ser funcionales a una maniobra contrarrevolucionaria, dependiendo del papel que cada organización le asignaba al fenómeno peronista. Clarificar ante los trabajadores y el pueblo el rol que jugaba este último, y el mismo Perón, se transformó entonces en una tarea de vital importancia para el PRT-ERP, que lo entendía como una "traba" para el desarrollo de la conciencia revolucionaria de los trabajadores.

Es de destacar, que entre los años 1973 y 1976 el PRT-ERP alcanzó su mayor crecimiento, teniendo presencia orgánica en muchas de las ciudades grandes y medianas del país y en las fábricas más importantes de cada una de ellas, impulsando el Movimiento Sindical de Base (MSB) como su herramienta sindical principal, y transformándose en una de las organizaciones de izquierda con mayor peso en el movimiento obrero ${ }^{8}$. Por su parte, las organizaciones del peronismo revolucionario, entre las que se destacó la Juventud Trabajadora Peronista (JTP), frente sindical de Montoneros, lograron un importante desarrollo, teniendo presencia en una gran cantidad de establecimientos fabriles de todo el país, en especial en el Gran Buenos Aires ${ }^{9}$. De este modo, la relación y los debates entre perretistas y peronistas revolucionarios formaron parte importante de la cotidianeidad militante al interior de muchas fábricas en las que se encontraron, influyendo, en distinta

\footnotetext{
${ }^{6}$ Tortti, op. cit.

7 Juan Carlos Torre, El gigante invertebrado. Los sindicatos en el gobierno 1973- 1976, Buenos Aires, Siglo XXI, 2004, 26.

${ }^{8}$ Pozzi, op. cit; Löbbe, op. cit; Santiago Stavale y Daniel De Santis, Un partido de la clase obrera. La política del PRTERP en el movimiento obrero, Ciudad Autónoma de Buenos Aires, Ediciones Finlandia, Colección A formar Filas, 2016.

${ }^{9}$ Federico Lorenz, Algo parecido a la felicidad. Una historia de la lucha de la clase trabajadora durante la década del setenta (1973-1978), Buenos Aires, Edhasa, 2013; Julieta Pacheco, "Análisis de la militancia sindical de Montoneros: La Juventud Trabajadora Peronista y sus luchas”, e-1@tina, Vol. 13, Nro. 50, 2015.
} 
medida, en la experiencia de una porción de la clase obrera argentina que venía construyendo una relación dinámica con las organizaciones de la nueva izquierda.

En el presente artículo analizaremos los fundamentos y la forma que asumió la polémica que entablo el PRT-ERP con la TRP (fundamentalmente con las Fuerzas Armadas Revolucionarias y los Montoneros) en el marco de la apertura democrática y del retorno del peronismo al gobierno. Para ello reconstruiremos los debates fundacionales y las bases teóricas desde las cuales dicho partido construyó su interpretación del peronismo, la forma en que analizó el retorno de Perón y la estrategia que se dio para traccionar al peronismo revolucionario hacia la unidad de acción al interior de las fábricas. Al mismo tiempo indagaremos sobre los niveles de unidad que alcanzaron en algunos casos específicos. Buscamos avanzar sobre una hipótesis inicial que supone que la "unidad en la acción" se dio fundamentalmente en el plano sindical, y que ésta estuvo motivada por la práctica de los militantes fabriles que tendieron a dejar de lado las discusiones político-ideológicas que mantenían las direcciones de sus organizaciones, y priorizaron la coordinación en acciones comunes e organismos de base en la lucha contra su enemigo común: la burocracia sindical ${ }^{10}$. La importancia de indagar como se dieron estos vínculos reside en que tanto el PRT-ERP como las organizaciones de la TRP, aun con sus diferencias, concebían a la clase obrera como el sujeto de la revolución y que, por ende, la línea de intervención y las alianzas tejidas en ese frente fueron expresión de las estrategias y posiciones que fueron asumiendo durante el período.

Es necesario destacar que existen un conjunto de trabajos que han estudiado el vínculo entre la nueva izquierda y el movimiento obrero y que, directa o indirectamente, analizan experiencias en la que dicho vínculo fue explícito. Por un lado nos encontramos con obras que, con sus diferencias, han reconstruido y analizado de manera general las experiencias antiburocráticas de la época y el rol que jugaron las organizaciones revolucionarias en su seno ${ }^{11}$. Por otro lado se hallan un conjunto de estudios de caso en los que se busca reconstruir experiencias puntuales donde dichas corrientes tuvieron un especial protagonismo y, aunque no se dedican a analizar la relación entre las mismas, muestran la coordinación que alcanzaron y las distintas estrategias que asumieron en los $\operatorname{conflictos}^{12}$. Sin embargo, la unidad de acción entre el PRT-ERP y la TRP no ha sido un

\footnotetext{
${ }^{10}$ A lo largo del trabajo utilizaremos el concepto de burocracia sindical para referirnos a una capa de la clase obrera que, a través de la conducción de los organismos sindicales, oficia de intermediario tolerado por el capital, en su lucha contra la clase obrera, y juega un papel estratégicamente funcional al sistema de dominación capitalista, en su objetivo de evitar las luchas emancipadoras de los trabajadores. Cabe aclarar que, al mismo tiempo, buscamos alejarnos de las conceptualizaciones que construyen una idea de burocracia sindical como una dirigencia siempre opuesta a generar procesos de movilización y enfrentada a bases que constantemente estarían dispuestas a luchar y radicalizar los procesos. Entendemos que una definición como esa no permite entender la capacidad de adaptación y supervivencia de esta capa burocrática, los niveles de movilización que desplegó en algunos conflictos, así como también lleva implícita una visión idílica de la clase obrera que no permite ver sus reales comportamientos y aspiraciones. (Löbbe, Héctor: "Defendiendo al Capital: la burocracia sindical argentina en los “70” En: Revista Nuevo Topo No 7, pp. 25-39.)

11 James Brennan, El Cordobazo: guerras obreras en Córdoba, 1955-1976. Bs. As., Editorial Sudamericana, 1996, Hector Löbbe, op. cit., Pablo Pozzi, y Alejandro Schneider, Los setentistas. Izquierda y clase obrera: 1969-1976. Bs. As, Eudeba, 2000; Ruth Werner, y Facundo Aguirre, Insurgencia obrera en la Argentina. 1969-1976. Clasismo, coordinadoras interfabriles y estrategias de la izquierda, Ediciones IPS, Buenos Aires, 2007.

${ }^{12}$ Andrea Andujar y Agustín Santella, El Perón de la fábrica eramos nosotros. Luchas metalúrgicas de Villa Constitución 1970-1976., Buenos Aires, 1e ed, Desde el Subte, 2007; Mariano Casco Peebles y María Agustina Lenuda, "Conflicto
} 
tema específicamente abordado por la bibliografía. En ese sentido este artículo se propone avanzar en el análisis de esta dimensión.

\section{El peronismo, el GAN y las elecciones. Definiciones y debates}

\section{Hacia una definición marxista del peronismo}

La discusión sobre el carácter del peronismo y qué hacer frente a él se halla en la génesis del PRT-ERP ${ }^{13}$. Sin embargo el análisis teórico más acabado que la organización hizo sobre éste se halla en una serie de notas escritas por Luis Ortolani (dirigente de la organización), bajo el pseudónimo de Julio Parra, publicadas en el periódico El Combatiente entre los números 56 al 59 del año 1971, y compilados posteriormente en un folleto bajo el título $E l$ Peronismo ${ }^{14}$.

Allí el autor se propone realizar un análisis, tanto de las clásicas visiones conservadoras que caracterizaban al peronismo como un "movimiento fascista de la chusma descalzada" como de aquellas interpretaciones que lo entendían como un Movimiento Nacional. De este modo, Ortolani (y con él el PRT-ERP) realiza un análisis marxista sobre el peronismo, caracterizándolo como un "movimiento histórico que intentó un proyecto de desarrollo capitalista independiente, a través de un gobierno bonapartista que controlara a la clase obrera para apoyarse en ella"15.

En el documento se presenta al peronismo como fruto de una coyuntura histórica signada por la decadencia del imperio inglés y atravesada por la segunda guerra mundial, que habría hecho posible y necesario el desarrollo de un capitalismo independiente en Argentina. Este último, por no contar con una burguesía nacional fuerte, debió ser

obrero y acción guerrillera. La huelga en Mercedes Benz en 1975 y el secuestro de un nazi.” En: Archivos, año V, nro 9, septiembre de 2016, 97-116.; Harari, Ianina, "La burocracia peronista. El sindicato automotriz argentino ante el auge de la lucha de clases. 1969-1976" En: Revista IZQUIERDAS, año 3, número 8, 2010.; Federico Lorenz, op.cit; Florencia Rodríguez "Conciencia de clase y política. El caso de los obreros de Propulsora Siderúrgica. 1973-1975”, En: PYMSA, Documentos y Comunicaciones, 2010; Jorge Winter, La clase trabajadora de Villa Constitución. Subjetividad, estrategias de resistencia y organización sindical, Reunir, Buenos Aires, 2010

13 El PRT fue fundado en 1965 como el resultado de la fusión de dos organizaciones: el Frente Revolucionario Indoamericanista Popular (FRIP) y Palabra Obrera. Las dos organizaciones venían ya con un desarrollo incipiente en el movimiento obrero centrado fundamentalmente en los ingenios tucumanos y en algunas fábricas del Gran Buenos Aires y el Litoral. En la práctica ambas organizaciones habían delineado diferentes tácticas de inserción en el movimiento obrero que implicaban distintas formas de relacionarse con el peronismo. Es por ello que uno de los debates que atravesó la fusión fue sobre el "entrismo" practicado por PO. El "entrismo" consistía en una táctica que ponía como objetivo penetrar en las organizaciones sindicales peronistas asumiéndose como parte del "peronismo obrero revolucionario" para, una vez insertos en ellas, traccionar a los obreros a posiciones marxistas y revolucionarias. Esta táctica fue rechazada por la militancia del FRIP en el momento de la fundación y por el ala encabezada por Mario Roberto Santucho después, que será la que dirigirá, en la ruptura de 1968, al sector que formará el PRT - El Combatiente (que luego se conocerá como PRTERP). Para este sector el entrismo era una práctica oportunista que disfrazaba la propuesta revolucionaria y la ocultaba detrás de una identidad populista no permitiendo referenciar directamente al partido revolucionario. Para estos, los militantes partidarios debían construir una "salida de clase ideológicamente independiente", un "auténtico partido proletario" que, en el seno de las masas, de una batalla frontal contra la ideología burguesa de la conciliación de clases: el peronismo. (Pozzi, op. cit.; Stavale y De Santis, op. cit.)

${ }^{14}$ De Santis, op. cit., 119-159.

${ }^{15}$ Ibid., 120 
impulsado por el sector más lúcido de las fuerzas armadas, que encontró en la clase obrera el único sostén para ese desarrollo, ganándose su apoyo y al mismo tiempo controlándola. Allí residía para el PRT-ERP el carácter bonapartista del peronismo.

Esta característica explicaba a su vez su carácter contradictorio que lo llevaba a un callejón sin salida: para garantizar la expansión industrial, tarde o temprano, iba a tener que garantizar la superexplotación de los trabajadores arriesgando el respaldo masivo que le brindaba la clase obrera y haciendo inviable la alianza policlasista. Es por ello que, aunque desde el punto de vista político el peronismo era un fenómeno vivo y actuante, el PRT-ERP lo entendía como un fenómeno "histórica e ideológicamente agotado".

Por otro lado, si bien en el documento se lo analizaba como la primera etapa en la formación de la conciencia de la clase obrera argentina, es decir, como el momento en que los trabajadores comenzaron a reconocerse como clase, no dejaba de entenderlo como una traba objetiva para el desarrollo de la conciencia revolucionaria.

Ahora bien, el PRT-ERP distinguía dos tipos de peronismo: uno revolucionario, combativo y progresista, que expresaba a los obreros, campesinos pobres, pobres de la ciudad, pequeños burgueses y sectores progresistas de la burguesía media; y otro burgués y burocrático, expresión de la gran burguesía y de la burguesía media reaccionaria. El problema residía en que ambos estaban formalmente unidos por el liderazgo de Perón, y éste, para los perretistas, era el jefe del "peronismo burgués".

En este marco, si bien el PRT-ERP evaluaba que la clase obrera estaba viviendo una "intensa revolución ideológica"16, encarnada sobre todo en las nuevas generaciones que habían protagonizado los "cordobazos", los "rosariazos" y las demás gestas antidictatoriales y antiburocráticas, no dejaba de reconocer que existían extensos sectores de la clase obrera que seguían bajo el influjo del peronismo.

Ese análisis le permitía a la organización evaluar que, para la burguesía, el peronismo, y más específicamente Perón, podía transformarse en el último y más efectivo recurso para defender al sistema capitalista argentino ante la avanzada de las organizaciones revolucionarias. De este modo, el PRT-ERP ya en 1971 vaticinaba que el retorno del viejo líder sería la última de las cartas que tendrían las clases dominantes para frenar la lucha revolucionaria, análisis que, entendemos, se demostraría correcto poco tiempo después.

El rol contrarrevolucionario que la organización preveía iba a jugar Perón con su retorno, acrecentaba la necesidad de profundizar el debate con las corrientes que le otorgaban a este último el papel de líder revolucionario, despertando "falsas esperanzas" entre la vanguardia obrera: "Las organizaciones armadas peronistas participan en la guerra del pueblo planteando el retorno de Perón. Y Perón teje el Gran Acuerdo Nacional con Lanusse, instrumento que éste ha elaborado precisamente para frenar la guerra revolucionaria" $"$.

De esta caracterización, la organización concluía que los revolucionarios debían tomar dos actitudes frente al peronismo: por un lado fomentar la unidad en la acción

16 "El único camino hasta el poder obrero y el socialismo" En: Daniel De Santis, A vencer o morir. Historia del PRT-ERP: documentos. Tomo 1 Volumen 1, Buenos Aires, Nuestra América, 2004, 141-212.

17 De Santis, op. cit., 155 
fundamentalmente con sus organizaciones armadas y sus corrientes combativas del movimiento obrero y por otro lado, y al mismo tiempo, dar una profunda lucha ideológica contra sus propuestas burguesas y "contrarrevolucionarias", denunciando el GAN, la salida negociada de la dictadura, y combatiendo a su conducción política y sindical. La militancia perretista debía ayudar a agudizar las contradicciones entre las aspiraciones revolucionarias de los sectores combativos y las tácticas conciliadoras de la dirección oficial del movimiento, al tiempo que traccionar o neutralizar a los sectores de la mediana o pequeña burguesía peronista.

\section{Democracia vs Revolución: el dilema de las elecciones}

Estas dos "actitudes" asumieron especial relevancia hacia 1973. La convocatoria a elecciones pautada para marzo y el protagonismo que asumieron los sectores revolucionarios del peronismo en la campaña electoral del Frente Justicialista de Liberación (FREJULI), encabezada por la fórmula Cámpora-Solano Lima, era, para la organización, una demostración práctica de la influencia que el "peronismo burgués" ejercía en estos sectores, y del éxito de la maniobra pergeñada por las clases dominantes.

La nueva coyuntura ponía sobre la mesa del debate el problema de la "democracia" y la "revolución"18. Las diferencias entre el PRT-ERP y la mayoría de las organizaciones de la TRP no residían en la crítica y la desconfianza hacia la "democracia burguesa" ya que, con matices, compartían la certeza de que la toma del poder sólo podía realizarse a través de la guerra revolucionaria y que la "democracia representativa" debía reemplazarse por una verdadera "democracia revolucionaria". Nuevamente las discrepancias estaban en la caracterización que unas y otras hacían del movimiento peronista y de Perón y de los significados que le atribuían tanto a la convocatoria a elecciones como un posible triunfo electoral peronista. Montoneros entendía a las elecciones como un aspecto más de la "guerra integral" ya que, según sus análisis, había sido el mismo Perón el que le había arrancado las elecciones al régimen. De este modo un triunfo del peronismo en este plano era un paso clave en la "liberación nacional" que allanaba el camino para lo que la organización peronista entendía como una segunda etapa del proceso revolucionario: la "liberación social". La tensión que generaba participar de un proceso cuya legitimidad se basaba en la legalidad democrático-burguesa se resolvía en la convicción del papel revolucionario que, según estos, jugaba Perón, y en el hecho de que la alianza de clases cristalizada en el FREJULI se correspondía a las tareas nacionales de la etapa ${ }^{19}$.

\footnotetext{
${ }^{18}$ El debate democracia-revolución atravesó a todas las organizaciones de la nueva izquierda en argentina, así como al resto de las organizaciones revolucionarias del continente latinoamericano. La experiencia frustrada de la "vía chilena al socialismo" ensayada por Salvador Allende y la Unidad Popular en el año 1973 reactualizó los debates sobre "reforma y revolución", siendo interpretado por la mayoría de las organizaciones revolucionarias como una "lección" contra tentativas "reformistas", reforzando la desconfianza en la democracia burguesa y la convicción de la vía armada para la revolución. Para profundizar sobre este tema ver: Mariano Zarowsky, Reforma y revolución: la vía chilena al socialismo en la nueva izquierda intelectual argentina, Izquierdas, 29:133-148, septiembre 2016.

${ }^{19}$ Es necesario remarcar que con el retorno del peronismo al gobierno se abrieron debates al interior de la Tendencia Revolucionaria del Peronismo que durante la dictadura habían sido relegados por una unidad inestable en torno a la difusa idea de que Perón y el peronismo eran revolucionarios. La crisis de aquellos acuerdos mínimos tuvo por resultado la consolidación de dos posturas diferentes: la primera fue la posición movimientista, que acentuaba el carácter nacional de
} 
Para el PRT-ERP, en cambio, el escenario era totalmente distinto: su convicción de que las tareas nacionales y sociales de la revolución eran inescindibles, su rechazo a todo intento de conciliación de clases, su caracterización de la "democracia burguesa" como la mejor y más desarrollada forma de dominación política de las clases dominantes, sumado al análisis antes expuesto sobre el papel que, creían, venían a jugar las elecciones y el retorno de Perón, le planteaba el difícil dilema de cómo intervenir en dicho contexto.

Finalmente el PRT-ERP definió como táctica "movilizar a los más amplios sectores de masas con un programa democrático" 20 intentando tener una participación propia en las elecciones con candidaturas surgidas de los barrios y fábricas donde tenía trabajo político ${ }^{21}$. Sin embargo, "convencidos de la esterilidad de la participación electoral" ${ }^{22}$, los militantes perretistas volcaron la mayoría de sus esfuerzos y recursos al accionar armado y no asumieron con decisión las tareas legales necesarias para concretar la intervención. Esta actitud se vio fortalecida por los análisis de la organización que pronosticaban que las masas asistirían a las urnas sin ninguna esperanza de cambio, algo que poco tiempo después se vería refutado por el contundente triunfo electoral peronista.

De este modo, frustradas las posibilidades de una participación con listas propias, y descartada la opción del boicot electoral, finalmente la organización terminó adoptando una política abstencionista que limitó su intervención al lanzamiento de un volante agitativo del ERP con consignas programáticas a repartir el día de la elección ${ }^{23}$.

Es de destacar que estas definiciones no se dieron sin sobresaltos sino que, por el contrario, motivó el surgimiento de una fracción al interior de la organización que, haciendo un análisis distinto de la nueva etapa abierta, se volcó a acompañar la experiencia del FREJULI creando el "ERP-22 de Agosto"24. Aunque el proceso fraccional y la posterior

la revolución, vinculándola a la liberación nacional sin que ésta implique necesariamente, liberación social. Se consideraba que tanto Perón como su Movimiento eran revolucionarios y aunque denunciaban la existencia de "traidores" en su interior, las diferencias eran puestas en segundo lugar priorizando la unidad del peronismo. Enfrentando a esta postura, se erigía el "alternativismo" que consolidaba una posición clasista y afirmaba que no habría liberación nacional sin revolución social. Remarcaban la existencia de contradicciones irreconciliables al interior del Movimiento expresadas en las burocracias sindicales-políticas y en la pretensión de una alianza imposible con la burguesía nacional. Se entendía a la clase obrera como sujeto revolucionario y la necesidad de construir una Alternativa Independiente (AI) al Movimiento. El debate entre movimientistas y alternativistas atravesó a la izquierda peronista desde 1971 en adelante, impidiendo su unidad estratégica. La discusión tensionó a sus organizaciones más influyentes; Montoneros y JP (hegemónicas dentro de la Tendencia) sostuvieron posiciones cercanas al movimientismo mientras que fracciones de las Fuerzas Armadas Peronistas, el Peronismo de Base y organizaciones más pequeñas defendieron la Alternativa Independiente. (Mariela Stavale, "Peronismo para la Liberación Nacional ¿y social? El vínculo peronismo-revolución en las revistas Militancia Peronista para la Liberación y Envido, 1973”, Contemporánea № 7, Montevideo, 2016)

20 "Nuestra posición en la situación política actual" en El Combatiente Nro. 70 del 30 de julio de 1972

${ }^{21}$ Para ello, hacia comienzos de 1972, impulsó la formación de Comités de Base. Éstos intentaban ser espacios donde organizar a los pobladores de los barrios, obreros de fábricas, etc., bajo un programa "democrático, antidictatorial y antiimperialista". El objetivo declarado por la organización era canalizar la inquietud política de las masas de cara a la apertura electoral, creando instancias de participación en las que surgieran y se eligieran, entre otras cosas, candidatos para una posible intervención con listas propias.

${ }^{22}$ Pozzi, op. cit, 301

23 “La toma del batallón y las elecciones" en El Combatiente Nro. 74, primera quincena de marzo de 1973.

${ }^{24}$ La nueva organización criticaba al PRT-ERP por su posición abstencionista aduciendo que esa línea de intervención los dejaría ajenos al proceso de movilizaciones de masas antes y después del triunfo electoral peronista. El ERP-22 consideraba que el FreJuLi era la herramienta, imperfecta pero real que el pueblo había forjado para derrotar a la 
ruptura no tuvieron demasiada repercusión, por tratarse de un reducido grupo con escasa influencia al interior del partido, la experiencia del ERP-22 demuestra que el debate sobre el peronismo, y más específicamente sobre el escenario de la apertura democrática, tuvo costos para el PRT-ERP. ${ }^{25}$

\section{La polémica y el llamado a "la unidad de los revolucionarios". Dos aspectos de una misma tarea}

La polémica con las organizaciones del peronismo revolucionario ya había comenzado incluso antes de la publicación de El Peronismo. Entre abril y noviembre de 1971 se había desarrollado un intenso debate entre el PRT-ERP y las Fuerzas Armadas Revolucionarias (FAR), motivado por la publicación de un reportaje realizado a esta última organización en la revista Cristianismo y Revolución ${ }^{26}$. La importancia de este debate radicó, no solo en su profundidad teórica y política, sino, fundamentalmente, en que enfrentó dos formas de entender y de aplicar el marxismo a la realidad argentina: por un lado la sostenida por las FAR que ubicaba al marxismo en el lugar de guía o herramienta para el análisis, pero no como doctrina, ideología ni "bandera política universal"27. Desde esta concepción era la "experiencia del pueblo", el fundamento último de la verdad. En contraposición, los militantes perretistas sostenían una versión del marxismo como concepción del mundo, como una guía para la acción y como la ideología de la clase obrera. De este modo, una y otra interpretación animaba dos posiciones opuestas ante el fenómeno peronista.

Así, en la entrevista, el líder de las FAR, Carlos Olmedo, define a su organización en el marco de una estrategia de "nacionalismo revolucionario", lo que implicaba una valoración positiva del peronismo, calificándolo como una experiencia fundamental para el pueblo argentino y asumiéndolo plenamente como la identidad de la organización. Para el dirigente guerrillero, el peronismo y el antiperonismo era la forma en que se manifestaba la lucha de clases en Argentina, por lo que el socialismo solo podía lograrse con la victoria del pueblo peronista ${ }^{28}$.

Esta larga entrevista motivó la respuesta casi inmediata de un grupo de militantes perretistas, encabezados por el dirigente Domingo Menna, que estaban bajo prisión en la cárcel Encausados de Córdoba. En el breve documento titulado Responde el ERP, el concepto fundamental de la respuesta estaba en la idea de que no era científicamente posible una tercera ideología entre la burguesa (capitalista) y la proletaria (socialista) y que

\footnotetext{
dictadura, y que su triunfo era la culminación de la primera etapa de un proceso que debería terminar en una verdadera revolución. (Liberación Nro. 4, 22 de Mayo de 1973; Liberación Nro. 1, 16 de Marzo de 1973)

${ }^{25}$ Según Eduardo Weiz en la conformación de la fracción confluyen dos procesos independientes: por un lado, el debate sobre el peronismo y el trabajo de masas sostenido por "Cacho Ventricci" y por el otro una discusión sobre los métodos de la dirección, y sobre la preparación de los operativos militares, que preocupaba centralmente al Comité Militar de la regional, dirigido por el Gallego Fernández Palmero y Jorge Belomo. (Weiz, op. cit., 139)

26 "Los de Garín", Cristianismo y Revolución; Nro. 28 (abril de 1971); 56-70.

${ }^{27}$ Esteban Campos, "Marxismo, ideología y experiencia en el debate entre las FAR y el PRT-ERP” Unité Mixte de Recherche Mondes américains; Nuevo Mundo Mundos Nuevos; 2013; 12-2013; 1-20

${ }^{28}$ Esteban Campos, "La cuestión del peronismo en el debate entre las FAR y el PRT-ERP", Anuario Nro. 25, Escuela de Historia Revista Digital Nro.4, FHumyAr, 2013, 287
} 
por ello el peronismo podía albergar en su seno las figuras más retrogradas y contrarrevolucionarias sin ser inconsecuente.

Es de destacar que pese al debate, ambas organizaciones realizaron acciones conjuntas a lo largo del año 1972, como la ejecución del General Juan Carlos Sánchez (Comandante del II Cuerpo de Ejército de Rosario acusado de instalar en la zona el "más bárbaro régimen de tortura contra los combatientes populares de que se tenga noticia" 29 ) y la fuga, de dirigentes y militantes de ambas organizaciones del penal de Rawson. Sin embargo, esta coordinación generó cierto desconcierto y molestias entre las organizaciones de la TRP, fundamentalmente en Montoneros, lo que empujó a las FAR a diferenciarse cada vez más del PRT-ERP y priorizar los vínculos con las organizaciones peronistas ${ }^{30}$.

Finalmente, el alejamiento cada vez más notorio entre ambas organizaciones fue acelerándose hacia el año 1973 ante la inminente apertura democrática y retorno de Perón a la Argentina. En consecuencia, en enero de ese año, el PRT-ERP envió una carta a las FAR advirtiéndoles de lo que entendía como un profundo error. En la misiva se criticaba la decisión de las FAR de suspender todo tipo de coordinación y de acción conjunta y, sobre todo, de participar de la maniobra electoral pactada entre Perón y la dictadura militar ya que de esa manera estarían minando los avances hacia la unidad de los revolucionarios.

El PRT-ERP analizaba que el peronismo se estaba transformando en una "cuña" entre las organizaciones armadas, dividiendo al campo de los revolucionarios entre aquellos que lo apoyaban, y por ende eran funcionales a la "maniobra contrarrevolucionaria", y quienes lo enfrentaban. Bajo este razonamiento, para los perretistas esto fortalecía el poder del enemigo, por lo que la organización intensificó el debate con aquellas corrientes que continuaban renovando la confianza en el liderazgo de Perón.

Desde principios de 1972, y a lo largo de todo el año 1973, se pueden encontrar en cuantiosos números del periódico El Combatiente llamados de unidad a las organizaciones de la TRP, más específicamente a las Fuerzas Armadas Peronistas (FAP), FAR, Descamisados y Montoneros. Tomando el año 1973, encontramos que, de los veintisiete números publicados de El Combatiente, al menos veintitrés de ellos contienen un pasaje dedicado a discutir con el peronismo revolucionario. Desde apartados o comentarios en sus editoriales, pasando por notas centrales, la publicación de cartas de obreros desencantados con el gobierno peronista, hasta la reproducción de una solicitada publicada por distintas agrupaciones del propio peronismo revolucionario disidente, se transformaron en algunos de los repertorios que utilizó la organización para polemizar con estas corrientes.

Ya en marzo de ese año, en El Combatiente Nro. 76, el PRT-ERP se preguntaba y se respondía ante el triunfo electoral del peronismo: “¿Quién tiene razón en su alegría? ¿Los que esperan -como Frondizi- un gobierno peronista que haga la "revolución nacional", es decir, que salve al capitalismo de su crisis? ¿O los que creen -como las organizaciones armadas peronistas- en una verdadera revolución, en la revolución socialista? Sin duda que es Frondizi el que está en lo cierto."31

29 "El largo brazo de la justicia popular" (De Santis, op.cit, 227)

${ }^{30}$ Mora González Canosa, Las Fuerzas Armadas Revolucionarias: Orígenes y desarrollo de una particular conjunción entre marxismo, peronismo y lucha armada (1960-1973), FaHCE-UNLP, Tesis de posgrado, 2012.

${ }^{31}$ El Combatiente Nro. 76. Segunda quincena de Marzo de 1973 
Esta posición, a su vez, se vio reflejada en la respuesta al pedido de tregua del Presidente Cámpora, aparecida en abril. En ella el PRT-ERP manifestaba su decisión de no atacar al nuevo gobierno en tanto este no atacara al pueblo y a la guerrilla, reconociendo la voluntad popular, pero, al mismo tiempo, no aceptando suspender el enfrentamiento militar contra las fuerzas armadas y las empresas monopólicas, ya que eso significaba "darle una tregua al enemigo". Esta decisión partía de la certeza de que la nueva administración, por su composición, su programa y sus métodos, no podía de ninguna manera significar un paso efectivo hacia la liberación nacional y social, sino que, por el contrario, tenía el objetivo de "engañar a las masas y su vanguardia". El documento, en ese sentido, era, por elevación, una llamado de atención para los sectores revolucionarios y progresistas del peronismo, con un mensaje claro: "todo aquel que manifestándose parte del campo popular intente detener o desviar la lucha obrera y popular en sus distintas manifestaciones armadas o no armadas con el pretexto de la tregua y otras argumentaciones, debe ser considerado un agente del enemigo, traidor a la lucha popular, negociador de la sangre derramada" 32 . El camino, por el contrario, debía ser el de la unidad de las organizaciones armadas para redoblar la lucha en todos los terrenos y no darle tiempo "al enemigo" a que prepare una contraofensiva.

En esa misma dirección, en el mes de julio, con el título "El PRT a los compañeros del peronismo revolucionario" y bajo el epígrafe "¡Por la unidad de las organizaciones armadas!", la organización le dedica la nota central de El Combatiente Nro. 81 a confrontar las posiciones vertidas por las FAR y Montoneros en una conferencia de prensa conjunta dada en junio de ese año y publicada en el periódico El Descamisado. A lo largo de la nota los autores buscan desarmar los argumentos planteados por las organizaciones peronistas, que sostenían que el FREJULI, era una alianza de clases para enfrentar al imperialismo, siendo Perón el líder indiscutido en esa contienda, y que "(...) para ser revolucionarios en nuestro país es necesario asumir la experiencia histórica de nuestro pueblo, que es el peronismo; por lo tanto aquellos que lo enfrenten o lo ignoren quedan al margen de la historia real y no pueden autodenominarse revolucionarios"33, en alusión directa al ERP. Los argumentos perretistas versaban en las declaraciones que el propio Perón había realizado, demarcando al peronismo de cualquier expresión izquierdista y revolucionaria y fundamentalmente en los hechos ocurridos en Ezeiza ${ }^{34}$ que, para el PRT-ERP, eran una clara confirmación del papel contrarrevolucionario que venía a jugar el viejo caudillo. En ese sentido la conclusión era contundente: "No es posible organizarse en defensa de los intereses de la clase obrera mezclados con sus enemigos y subordinados a sus enemigos $(\ldots)^{m 35}$.

A lo largo del año y de las publicaciones, el debate fue tomando un carácter cada vez más confrontativo. A pesar de las expectativas del PRT-ERP puestas en una posible

\footnotetext{
32 "Porque el Ejército Revolucionario del Pueblo no dejará de combatir" (De Santis, op. cit., 360)

${ }^{33}$ El Descamisado Nro. 4.12 de junio de 1973

${ }^{34}$ El 20 de Junio de 1973, se dio una de las mayores movilizaciones populares para recibir a Perón en su retorno, que terminó en una masacre propiciada por las organizaciones de la derecha peronista que, encaradas de la seguridad de los palcos oficiales, abrieron fuego contra las columnas de los militantes de la izquierda peronista que se acercaron al lugar (Ver: Horacio Verbitsky, Ezeiza, Buenos Aires, Editorial Contrapunto, 1985).

${ }^{35}$ El Combatiente Nro. 81. Lunes 16 de Julio de 1973
} 
"rectificación" de las organizaciones revolucionarias del peronismo, los hechos demostraban lo contrario. Las "vacilaciones" de Montoneros y las FAR ante el Pacto Social, la pasividad ante la renuncia inducida del presidente Cámpora, y la infranqueable decisión de continuar bajo un gobierno que daba claras señales de derechización, sumado a las críticas que estas organizaciones le realizaban por no abandonar la actividad militar, llevaron a este partido a elevar el tono de sus advertencias:

Los que pueden quedar aislados, -y aún peor, hacer el juego al enemigoson los compañeros, al romper la unidad de los revolucionarios (...) se sientan a la misma mesa con sus peores enemigos, con enemigos feroces del pueblo, las bandas fascistas de Brito Lima y compañía y embellecen a nuestros peores enemigos, las FF.AA contrarrevolucionarias ${ }^{36}$.

En ese mismo tono continuará la polémica a lo largo de 1974. Hasta ese momento, salvo contadas excepciones, Montoneros había optado por evitar sostener la polémica con los perretistas ignorando los debates propuestos por éstos y concentrándose en la disputa interna al interior del movimiento peronista. Sin embargo, en el mes de enero la organización rompió el silencio. El día 19 de ese mes la compañía "Héroes de Trelew" del ERP atacó el Regimiento de Tiradores Blindados ubicada en la localidad bonaerense de Azul lo que motivó una dura respuesta de Perón quien utilizó el hecho para endurecer su política represiva y avanzar contra las posiciones de gobierno que todavía conservaba la $\mathrm{TRP}^{37}$. La acción fue repudiada o criticada por la mayoría de las organizaciones y expresiones de la tendencia revolucionaria. Montoneros, desde El Descamisado, era contundente a la hora de definir al ERP como un "grupo minoritario", "extraños al pueblo", alejados de la realidad política y a los que debía tratárselos como un problema policial si no entraban en razones. Más allá de que el mensaje montonero estaba cargado de exabruptos dirigidos a morigerar la reacción del viejo líder, las diferencias eran explicitas: para estos últimos el problema estaba en que los perretistas tenían una posición cerrada y no distinguían las profundas diferencias que había entre "un gobierno popular con contradicciones internas" y la dictadura militar ${ }^{38}$. Por su parte desde las páginas de la revista Militancia Peronista para la Liberación, publicación peronista que expresaba las posiciones del Peronismo de Base y las Fuerzas Armadas Peronistas, calificaban a la acción como "inexplicable" en el marco de la lucha contra la legislación represiva que venían llevando adelante los sectores populares ${ }^{39}$.

El PRT-ERP en cambio reivindicaba la acción porque, según el propio Mario Roberto Santucho, habría ayudado a desenmascarar definitivamente a Perón y mostrarlo

\footnotetext{
${ }^{36}$ El Combatiente Nro. 92. Viernes 28 de Septiembre de 1973

${ }^{37}$ Luego de la acción Perón responsabilizó al gobernador de la provincia de Buenos Aires, Oscar Bidegain, afin a la TRP, quien se vio forzado a renunciar. En un mismo sentido el viejo líder envió al parlamento un proyecto de modificación del Código Penal para intensificar la legislación represiva.

${ }^{38}$ El Descamisado Nro. 37. 29 de Enero de 1974.

${ }^{39}$ Militancia Peronista para la Liberación Nro. 32. 24 de Enero de 1974. Militancia fue una importante revista del peronismo de izquierda, dirigida por Ortega Peña y Eduardo Luis Duhalde que se editó entre 1973 y 1974 y fue finalmente clausurada por el gobierno peronista. Alineada con el clasismo de la Alternativa Independiente del PB y las FAP, discutió en reiteradas ocasiones con las posiciones de Montoneros y la Juventud Peronista.
} 
"tal cual es, el Jefe de la Contrarrevolución". Por otro lado, calificaba a la reacción de la TRP como una muestra más de sus "vacilaciones" y de la influencia que ejercía sobre ellas la burguesía. Sin embargo, al mismo tiempo, llamaba a la militancia perretista a ser "pacientes" con dichas organizaciones manteniendo "con firmeza desde un punto de vista proletario una consecuente política unitaria."40

A lo largo del año, en las páginas de El Combatiente, se siguieron publicando artículos de debate directo con Montoneros y la Juventud Peronista, desde los cuales se profundizaba el debate ideológico, se insistía en el llamado a la autocrítica y la rectificación de sus posiciones "zigzagueantes" y se les advertía sobre la "maniobra de pinzas" que, según los perretistas, estaba impulsando el gobierno y de la que estas organizaciones estaban siendo víctimas y cómplices.

En el mes de abril, la organización dedicó tres notas en dos números contiguos del periódico $^{41}$, en las que combinaban la denuncia, la advertencia y el llamado a la unidad. Así, bajo los títulos "Fortalecer la unidad del campo popular", "Juventud Peronista: Una declaración lamentable" y "Dos tácticas en la lucha de clases", el PRT-ERP denunciaba, de distintas maneras, que mientras estas organizaciones seguían especulando "con la posibilidad de imponer su peso dentro del movimiento peronista", terminaban siendo funcionales a un gobierno cuyo objetivo era, mediante "periódicos "reacercamientos" y "concesiones aparentes", destruirlos a ellos mismos, reprimir a la guerrilla y "meter nuevos cuños en la aún no consolidada unidad del campo popular." Bajo este diagnóstico, la organización hacía un nuevo llamado a Montoneros y la Juventud Peronista a que hagan una "seria autocrítica de los errores cometidos" y "corrijan a tiempo su política equivocada", escuchando a sus bases obreras y apostando a la unidad del campo popular "en la línea de no alentar más falsas esperanzas en las maniobras del enemigo y golpear todos juntos para desbaratarlas" $" 42$.

Sin embargo, las preocupaciones ya no pasaban solamente por la falta de unidad de las organizaciones revolucionarias, sino directamente por el rol que estas organizaciones comenzaban a cumplir en el seno de la clase obrera a los ojos perretistas. De este modo, el apoyo por parte de estas corrientes a la Ley de Asociaciones Profesionales y a la Ley de Prescindibilidad (que buscaban, respectivamente, fortalecer el poder de la burocracia sindical y habilitar los despidos indiscriminados) era calificado como una "viva muestra de una política de colaboración de clases, de peligrosos entendimientos con la burguesía"43. En esta dirección, el PRT-ERP llegó a plantear hacia septiembre de 1974 que Montoneros era una "organización populista al servicio de las ilusiones nacionalistas burguesas" 44 . Paradójicamente, para la misma época, un grupo importante de militantes montoneros abandonaban la organización haciendo la acusación inversa. Decidieron formar la JP Lealtad por considerar inaceptable el "enfrentamiento" de Montoneros con Perón ${ }^{45}$, y

40 "Después de Azul: balances y perspectivas" El Combatiente Nro. 105. Miércoles 30 de enero de 1974.

${ }^{41}$ El Combatiente Nro. 113 del 10 de abril de 1974 y El Combatiente Nro. 114 del 17 de abril de 1974

42 "Fortalecer la unidad del campo popular" El Combatiente Nro. 113. 10 de abril de 1974

43 "Las vacilaciones del campo popular" en El Combatiente Nro. 125 de julio de 1974

${ }^{44}$ El Combatiente Nro. 134. 11 de septiembre de 1974

${ }^{45}$ Pozzoni Mariana, "Los orígenes de la Juventud Peronista Lealtad: los soldados de Perón (1973-1974)”, Cuadernos del CLAEH, Segunda serie, año 34, Nro. 101, 2015; 22-61. 
remarcando las dificultades que tenía esta última para lograr diferenciarse del PRT-ERP: "Tendenciosos y ultras acuden a los mismos lugares a tratar de sacar partido de cada conflicto sindical (...) queriendo convertir las luchas por reivindicaciones concretas en una sola y feroz batalla contra el Pacto Social (...)"46. Sin embargo, estas discusiones en el seno de la organización montonera no modificaron la caracterización perretista.

Diferente era la valoración que hacía de organizaciones como el Frente Revolucionario Peronista, Acción Revolucionaria Peronista, el Ejército de Liberación Nacional, Montoneros Columna José Sabino Navarro, el Peronismo de Base y las Fuerzas Armadas Peronistas. Estas organizaciones componían, para el PRT-ERP, los sectores más lúcidos, "sanos", y "combativos", de la Tendencia Revolucionaria del peronismo ya que habían dado signos claros de independencia política frente al gobierno y asumían posiciones similares a las suyas aún continuando bajo esa identidad. En El Combatiente Nro. 97 se puede leer un balance de lo que la organización caracterizaba como la "crisis del peronismo" y en el que se destacaba a estas organizaciones como la punta de lanza del proceso de ruptura con la dirección "burguesa" al interior de la tendencia revolucionaria, y como un sector clave con el que se podía comenzar a avanzar hacia la conformación de un frente antiimperialista. La potencialidad de estos sectores, para los perretistas, residía en su decisión de construir al margen del movimiento justicialista y fundamentalmente en la ruptura con la noción de la conciliación de clases que los habría llevado desde un inicio a rechazar las políticas impulsadas por el gobierno (centralmente el "Pacto Social"), a denunciar el rol contrarrevolucionario de las FF.AA., y sobre todo a resaltar el carácter nacional y social (socialista) que debía asumir la revolución.

En la práctica, esto se manifestaba en la participación destacada de algunas de estas organizaciones en el Frente Antiimperialista por el Socialismo (FAS) ${ }^{47}$ impulsado por el propio PRT-ERP, así como en sus posiciones dentro del movimiento obrero.

A continuación, intentaremos analizar la forma que asumieron estas discusiones en el plano sindical y el tipo de coordinación que se lograron al interior de las fábricas.

\section{La unidad de acción en la lucha antiburocrática}

\section{La unidad de acción en la prescripción partidaria}

Como vimos, el PRT-ERP caracterizaba el proceso de apertura democrática como una maniobra de las clases dominantes para reactivar el capitalismo y, mediante la llamada

\footnotetext{
${ }^{46}$ Movimiento Nro.3. Primera quincena de Junio de 1974

${ }^{47}$ El FAS fue un frente de organizaciones, sindicatos, personalidades políticas, y sectores sociales no organizados, creado en agosto de 1973, que se organizó a través de un programa democrático, patriótico y antiimperialista, y llegó a convocar en su VI Congreso entre 25 y 30 mil activistas. El mismo fue impulsado centralmente por el PRT-ERP con el objetivo de formar un "embrión del frente de liberación nacional y social". En la práctica se trató de la respuesta organizativa al cambio de coyuntura política que encontraron un conjunto de organizaciones revolucionarias. En él participaron figuras como Silvio Frondizi, Armando Jaime, Alicia Eguren de Cooke, Manuel Gaggero, y un conjunto de organizaciones, entre las que se destacaron el Frente Revolucionario Peronista (FRP), Partido Comunista Marxista Leninista, Organización Comunista Poder Obrero, entre otras. (Ver: Mariel Esper Payo, "El Frente Antiimperialista y por el Socialismo, más que un 'ejercito político' impulsado por el PRT-ERP”, Questión, vol.1, nro 29, UNLP )
} 
“pacificación”, aislar a la vanguardia obrera y a las organizaciones guerrilleras para así "detener el proceso de guerra revolucionaria" que se había abierto en Argentina. ${ }^{48}$

En este marco, entendía que la clase obrera y sus organizaciones debían aprovechar los espacios legales abiertos y las contradicciones que poseía el nuevo gobierno. Como dijimos, los perretistas, a la par que daban la batalla ideológica con el peronismo, buscaban concretar la unidad de acción fundamentalmente al interior del movimiento obrero con sus tendencias combativas. Las nuevas condiciones de legalidad abrían el escenario para luchar por la democracia sindical y lanzarse a la calle por reivindicaciones que también compartían esos sectores del peronismo, entre las cuales figuraban los despidos, las subas salariales, la lucha contra el alza del costo de vida, contra la burocracia y por la libertad de los combatientes presos ${ }^{49}$. Ante ese diagnostico, el PRT-ERP resolvía luchar por la independencia del movimiento sindical del gobierno peronista, hacer frente a la "ofensiva ideológica y propagandística de la burocracia" y promover un amplio frente antiburocrático legal que le permitiera nuclear a todas las tendencias combativas que se venían gestando desde 1969. En ese sentido fue que el PRT-ERP pensó e impulsó al Movimiento Sindical de Base (MSB) ${ }^{50}$.

Es de destacar que ese mismo año Montoneros creó la Juventud Trabajadora Peronista (JTP) como su herramienta sindical que, dispuesta a dar la lucha en el seno de las 62 Organizaciones Peronistas, se lanzó a construir cientos de agrupaciones sindicales y se transformó en una de las fuerzas con mayor peso en los organismos de base fabriles como las comisiones internas y cuerpo de delegados ${ }^{51}$.

La militancia perretista debía enfrentarse al innegable peso del peronismo en las fábricas. Contra los pronósticos, análisis y expectativas del PRT-ERP, la apertura electoral había demostrado que la lealtad y la filiación política peronista de gran parte de la clase obrera argentina seguían siendo muy fuertes y eso se expresaba también dentro de la fábrica. Más allá de las dificultades que significaba la disputa con la burocracia sindical peronista, la militancia fabril perretista también debió enfrentarse al notable peso que adquirió la JTP. De este modo, la lucha ideológica en el seno del movimiento obrero se transformaba en una tarea urgente e impostergable para la organización. En consecuencia, el partido llamaba a sus militantes fabriles a no descuidar en ningún momento la "atención" de los obreros que estuviesen bajo la influencia del "reformismo", el "populismo" o el "espontaneísmo", "combatiendo con habilidad y eficacia la enfermedad políticoideológica" que supuestamente los afectaba y recuperarlos así "para la causa revolucionaria" 52 .

Ahora bien, es de destacar que el PRT-ERP hacía una diferenciación en la caracterización de la JTP respecto al resto de las vertientes organizativas de Montoneros, ya que consideraba que su componente obrero la llevaba a tener una actitud distinta, aceptando

48 "El triunfo electoral peronista y las tareas de los revolucionarios", El Combatiente Nro. 76 de marzo de 1973

${ }^{49}$ Sebastián Leiva Flores, "Teoría y práctica del poder popular, los casos del MIR, Chile, 1970-1973 y el PRT-ERP, Argentina, 1973-1976", Santiago de Chile, Universidad de Santiago de Chile, 2007, 92.

50 Santiago Stavale "¿Amplio frente sindical o brazo sindical perretista? Reconstruyendo la trayectoria del Movimiento

Sindical de Base”, VIII Jornadas de Sociología, FaHCE-UNLP, 2014, 13-14.

${ }^{51}$ Pacheco, op. cit., 5.

${ }^{52}$ El Combatiente Nro. 134. Miércoles 11 de Septiembre de 1974. 
frecuentemente la unidad en la lucha contra la patronal y la burocracia ${ }^{53}$. La lucha antiburocrática era un punto de contacto entre perretistas y peronistas revolucionarios que los unificaba al interior de las fábricas. Ambas corrientes coincidían en que los burócratas eran "traidores" que actuaban a favor de las patronales y de sus propios intereses y por ende eran enemigos a los que debían enfrentar en unidad. No obstante, es de destacar que partían de una explicación distinta sobre el origen y el carácter de la burocracia: para el PRT-ERP, ésta era una "formación parasitaria" surgida en el seno mismo de la clase obrera, por lo que su liquidación era un problema político e ideológico que la propia clase debía resolver, mientras que para Montoneros se trataba de un agente externo a la clase, su enemigo principal, un elemento infiltrado en el movimiento obrero que debía ser liquidado, por lo que consideraban legítimo, y un método necesario, el "ajusticiamiento" de sus máximos exponentes ${ }^{54}$.Es de destacar, además, que para ésta última organización la lucha contra la burocracia era parte esencial en su disputa al interior del movimiento peronista, no solo porque a sus ojos aparecían como uno de los "aliados" fundamentales del imperialismo al interior del mismo, sino porque con el desplazamiento de los dirigentes sindicales aspiraban a erigirse en la dirección del movimiento de liberación nacional en el que debía transformarse aquel ${ }^{55}$. Sin embargo, estas diferencias no significaron una traba para la unidad en la lucha antiburocrática, siendo éste el eje que permitió mayor articulación y coordinación entre ambos sectores, que, como vimos, encontraban mucha mayor distancia en lo relativo a la política nacional.

Ahora bien, esa lucha no estaba exenta de tensiones. Los compromisos adquiridos por las organizaciones del ala "movimentista" de la tendencia" ${ }^{56}$ con las políticas del gobierno, sobre todo durante 1973, llevaron a las organizaciones a chocar en algunos espacios de base ${ }^{57}$. De este modo, en El Combatiente de ese año pueden encontrarse denuncias a supuestas actitudes "desmovilizadoras", "sectarias" o "vaciladoras" de la JTP. Una de las denuncias más fuertes tuvo que ver con la decisión de haber votado y aceptado por "mero verticalismo" la Ley de Asociaciones Profesionales impuesta por Perón ayudando a fortalecer de este modo a las cúpulas sindicales. Por otro lado, se hacían denuncias más concretas. Tal es el caso, por ejemplo, del conflicto en Cerámica Santa Rosa, ocupada por sus trabajadores, en el que los militantes de la JP habrían instado a frenar la movilización planteando que había que tener confianza en el gobierno peronista ${ }^{58}$; o del acto convocado por la CGT cordobesa ante la escalada represiva en la que los

\footnotetext{
${ }^{53}$ El Combatiente Nro. 102. Miércoles 26 de Diciembre de 1973

${ }^{54}$ Para profundizar en este debate ver: Rafael Farace y Gabriela Jäkel, "Nociones sobre 'democracia obrera' y "burocracia sindical" en la izquierda de los años 70. Una comparación entre la izquierda peronista y la izquierda marxista”, Trabajo y sociedad Nro. 26, Santiago del Estero, 2016.

55 Julieta Pacheco, "La izquierda peronista y su inserción en el movimiento obrero", Revista Latino-americana de estudios do trabalho Nro. 19, año 19, 2014, 157-184.

${ }^{56}$ Se denominaba "movimientista" al sector del peronismo revolucionario compuesto por Montoneros (unificados con las FAR), la Juventud Peronista y sus organizaciones afines: Juventud Universitaria Peronista, Unión de Estudiantes Secundarios y Juventud Trabajadora Peronista.

${ }^{57}$ Denominamos espacios de base a los instrumentos organizativos de la clase obrera que limitan, al interior de las fábricas, el poder efectivo del capital en la primera línea del conflicto de clases (asambleas, cuerpos de delegado, comisiones internas, etc)

${ }^{58}$ El Combatiente Nro. 89. Viernes 7 de Septiembre de 1973
} 
militantes de la JP y la JTP habrían tenido una "actitud antiunitaria y "manijera"” intentando copar el acto e imponiendo sus propias consignas ${ }^{59}$.

A diferencia de organizaciones como el Peronismo de Base que tendían a coincidir y confluir con la política perretista, la estrategia de Montoneros no estaba puesta en construir una oposición clasista independiente, sino que estaba marcada por la disputa dentro del movimiento peronista y, por ende, por dentro de las 62 organizaciones.

Como vimos las diferencias también se manifestaban en la posición ante el Pacto Social, lo que repercutía directamente en el plano sindical. Sin embargo para marzo de 1974 Montoneros fue acercándose a la caracterización que venía sosteniendo el PRT-ERP desde la firma del acuerdo: desde el numero 44 de la revista El Descamisado llamaban a romper el pacto bajo el argumento de que éste era un acuerdo social para renegociar la dependencia ${ }^{60}$. Ahora bien, al mismo tiempo Montoneros siguió insistiendo en la necesidad de un acuerdo social, pero con una "verdadera" y preponderante participación de la clase obrera, lo que en algunos casos lo llevó a posiciones contradictorias en sus frentes obreros. No obstante, estas diferencias se manifestaron fundamentalmente al nivel del vértice de las organizaciones y no siempre se trasladaron a las experiencias concretas al interior de las fábricas. En ese sentido, como intentaremos demostrar a partir de ejemplos, consideramos que en algunos casos la unidad de acción se dio por la disposición del activismo obrero que, en la lucha por sus reivindicaciones concretas, tendió a priorizar las coincidencias por sobre las diferencias para enfrentar a la patronal y la burocracia. Esto además se vio favorecido por las posiciones más radicalizadas que asumió Montoneros a partir del 1 de mayo de 1974, con la grieta abierta en su relación con Perón y, luego de la muerte del viejo líder, cuando oficializan la ruptura política con el gobierno de Isabel Perón.

\section{La unidad de acción en la experiencia fabril}

En el presente apartado abordaremos algunos conflictos de los años 1974 y 1975 que nos permiten un primer acercamiento a la manera en que se dio la relación entre el PRT-ERP y las organizaciones de la TRP en las fábricas. Para ello nos concentraremos en tres casos que, en distintos grados, tuvieron trascendencia nacional por sus características, reivindicaciones y radicalidad, como fueron las luchas de los obreros metalúrgicos de Villa Constitución, así como los de la fábrica Propulsora Siderúrgica de Ensenada y de la automotriz Mercedes Benz Argentina ubicada en La Matanza. Los casos no fueron seleccionados sólo por ser representativos del tipo de conflictividad desarrollada en la época, sino porque permiten observar las tensiones, las modalidades y características que asumieron los vínculos entre perretistas y peronistas revolucionarios en los mismos.

La experiencia de la Lista Marrón y la lucha de los obreros de Villa Constitución han sido ampliamente analizadas en diversos trabajos ${ }^{61}$. El "Villazo", como se conoció el conflicto, se transformó en un símbolo de la lucha obrera y antiburocrática que suscitó la solidaridad de amplios sectores sociales. En éste se manifestaron distintas formas de

\footnotetext{
59“Actitud sectaria en el acto de Córdoba” en El Combatiente Nro. 101. Miércoles 19 de Diciembre de 1973

60 "Por qué hay que romper el Pacto Social” El Descamisado Nro. 44, 19 de Marzo de 1974.

${ }^{61}$ Andujar y Santella, op.cit.; Winter, op.cit.
} 
acción: la huelga, la ocupación, la asamblea masiva y permanente, la organización de un "comité de lucha", etc., en las que intervinieron la mayoría de las corrientes de la nueva izquierda como la JTP, el PST, VC, el PRT-ERP y Poder Obrero. Como destacan la mayoría de los autores, estas dos últimas jugaron un rol dirigente. Ahora bien, la relación entre las organizaciones no estuvo exenta de tensiones. Al haberse transformado en un conflicto con implicancias nacionales las diferencias políticas jugaron un papel preponderante en sus posicionamientos, dificultando por momentos la unidad de acción que venían construyendo las bases. Un ejemplo de ello fue la ausencia de la JTP en el "Plenario de la Democracia Sindical"62 realizado a comienzos de 1974, que pretendía ser una demostración nacional del movimiento obrero y antiburocrático. Esta decisión marcaba las diferencias que alejaban a esta corriente de la política impulsada por el PRT-ERP. La organización sindical montonera afirmó que no participó expresamente del acto por considerarlo "falto de representatividad" e "ineficaz" y por ser el resultado de acuerdos "superestructurales" entre las fuerzas políticas de izquierda. ${ }^{63}$ Más allá de este balance, es probable que la ausencia de la JTP haya tenido que ver con evitar enfrentarse al gobierno de Perón, ya que pocos meses después, con el viejo caudillo sin vida, la organización participó de plenarios similares junto a las organizaciones de izquierda sin realizar dichas consideraciones.

Estas diferencias se agudizaron aún más en la disputa por la dirección del conflicto villense. Las organizaciones que intervenían en la Lista Marrón, por momentos, asumieron una política sectaria que ponía en riesgo la experiencia. El PRT-ERP, como una de las principales fuerzas políticas del conflicto, no estuvo exento de estas actitudes. Un ejemplo de ello es relatado por Ángel Porcu, para ese momento responsable político de la organización en la localidad, a quien desde la dirección regional perretista le plantearon que debía construir el MSB, algo que hubiese ayudado a debilitar y dividir a la lista unitaria ya que, por otro lado, Montoneros también tenía en perspectiva construir una agrupación sindical propia. La negativa de Porcu motivó una reunión con miembros del Buró Político partidario para debatir a fondo el problema, y luego de una discusión intensa terminó prevaleciendo la posición del primero: "La conclusión final fue que en Villa Constitución no se creaba el MSB, por lo tanto, los trabajadores militantes del PRT seguimos siendo de la Marrón." 64

Como remarca Jorge Winter, este ejemplo muestra como estas tendencias supieron ser contrarrestadas por la voluntad de los propios integrantes de la Lista Marrón que priorizaron la amplitud que se necesitaba para garantizar el éxito de la lucha. Ese, de hecho, fue uno de los elementos que permitió que las disputas no obstruyeran el triunfo de la lista en noviembre del 74. Apenas dos meses después de estallado el "Villazo", en la localidad de Ensenada, provincia de Buenos Aires, los obreros de la fábrica Propulsora Siderúrgica tras una asamblea, que no contó con el apoyo oficial del sindicato, decidieron tomar la

\footnotetext{
${ }^{62}$ El plenario tuvo como oradores centrales a Alberto Piccinini de Acindar y a los dirigentes Agustín Tosco (Luz y Fuerza de Córdoba) y René Salamanca (SMATA Cordoba), transformándose en una importante demostración nacional del movimiento obrero opositor y antiburocrático, por lo que la ausencia de la JTP se tornaba aún más significativa.

63 "La unidad para la lucha fue una meta inalcanzable" La Justa. Órgano de la JTP. Nro. 2 de Junio de 1974

${ }^{64}$ Winter, op. cit.;76.
} 
fábrica en reclamo de aumentos salariales y el reconocimiento de la comisión interna provisora organizada durante el conflicto. El mismo estuvo encabezado por los integrantes de la Lista Blanca, agrupamiento gremial que había surgido en la lucha contra el oficialismo de la UOM y que un año atrás había sufrido un fraude electoral en manos de ésta última. Como destaca Florencia Rodríguez, a partir de 1973 había habido un cambio cualitativo en la dinámica electoral de la fabrica manifestado en que la existencia de dos listas no respondía a la antinomia peronismo-antiperonismo sino que expresaba dos modelos sindicales en disputa ${ }^{65}$. La Lista Blanca, de contenido profundamente antiburocrático, agrupaba en su seno a militantes del PB, JTP, PC, PCR, PST y PRT-ERP, algunos de los cuales formarán parte de la Comisión Interna Provisora (Omar "Turco" Cherri, Roberto Lopresti -JTP-, "Pato" Rave -PB-, Salvador Delaturi -PC- y Daniel De Santis -PRT-ERP-). En este caso si bien las líneas políticas de cada organización se expresaron en el conflicto, no fueron un obstáculo para la unidad que, como indican la bibliografía, fue garantía del triunfo obrero. De este modo, si la JTP denunciaba el incumplimiento del Pacto Social por parte de la empresa por el acaparamiento de material elaborado $^{66}$, por su parte los militantes perretistas intentaban darle un contenido fuertemente antipactista al conflicto, si unos tendían a focalizar en la disputa contra la burocracia, otros tendían a enfatizar la lucha contra la patronal ${ }^{67}$. Sin embargo estas diferencias no se tradujeron en conflictos dentro de la planta, sino que primó la capacidad de los dirigentes obreros para mantenerse unidos a pesar de sus diferencias estratégicas. ${ }^{68}$ Esto queda claro en el testimonio de Daniel De Santis, dirigente fabril perretista y miembro de la Comisión Interna Provisora:

... como la burocracia no venia, habíamos logrado instalar una dinámica muy reflexiva en el cuerpo de delegados (...) con el Truco Cherri [dirigente de la JTP] nos llevábamos diez puntos, que no es que el Truco venía con una línea y yo con otra y confrontábamos la línea con él, al contrario, nos juntábamos con el Turco y la línea salía de ahí $(. . .)^{69}$

Por su parte Jorge Orellano, trabajador de propulsora, simpatizante de la JTP y delegado fabril apunta que la relación entre PRT-ERP y Montoneros era buena y afirma:

\footnotetext{
${ }^{65}$ Rodriguez, op. cit., 181-182.

${ }^{66}$ Un volante firmado por la JTP en mayo de 1974 planteaba: "Desde hace un tiempo la Agrupación "Felipe Vallese" de trabajadores metalúrgicos de La Plata, Berisso y Ensenada, viene denunciando las maniobras de acaparamiento y desabastecimiento, que lleva adelante la empresa Propulsora Siderúrgica, al retener 100.000 toneladas de chapas laminadas en frío, que le reporta un beneficio económico de 6.000 millones de pesos, lo que significa que la patronal rompe el Pacto Social.” DIPPBA, Mesa B, Carpeta 39, Legajo 33. Localidad Ensenada, Tomo I, folio 195

${ }^{67}$ Mientras muchos de los volantes firmados por la JTP en el marco del conflicto terminaban con las consignas “¡liberación o vandorismo!" o "los sindicatos en manos del vandorismo significan 'dependencia”,, aquellos firmados por el PRT-ERP solían apuntar contra la empresa con consignas como "¡ninguna tregua a las empresas explotadoras!” y con un contenido claramente antigubernamental. DIPPBA, Mesa B, Carpeta 39, Legajo 33. Localidad Ensenada, Tomo I y II. ${ }^{68}$ Felipe Venero, "La izquierda y los trabajadores en Propulsora Siderúrgica durante el tercer peronismo 1973-1976" Jornadas Académicas de la Facultad de Humanidades y Ciencias de la Educación, Universidad de la República, Montevideo, 2015, 6; Rodríguez, op. cit.; 181-182

${ }^{69}$ Entrevista con el autor. La Plata, Septiembre 2014.
} 
"De hecho formaban parte del mismo cuerpo de delegados, jestaban mezclados! No había resquemores (...) entre ellos definían que es lo que se iba a hacer en determinado momento en medio del conflicto (...) más allá de ERP o Montoneros, los ideales eran los mismos

(...) nunca hubo un enfrentamiento por motivos por diferencias políticas, por el peronismo... por lo menos eso yo no lo noté"70

Como vemos fue la lucha antiburocrática la que permitió mayores puntos de contacto y logró en algunos casos un trabajo mancomunado entre peronistas revolucionarios y perretistas, haciendo que las líneas de intervención de cada organización no chocaran a nivel fabril sino por el contrario se presentaran prácticamente sin diferencias. Eso parecía estar claro para los militantes perretistas de la fábrica que en uno de sus volantes titulado "El camino del triunfo" apuntaban que "en lo organizativo y lo político debe primar por sobre todo la unidad de clase, por los objetivos comunes, por los problemas más inmediatos de todos los compañeros, así debemos agruparnos todas las corrientes y compañeros independientes en un solo camino."71 Como vemos, las discrepancias más profundas se manifestaban en un nivel ideológico y estratégico que no impedía la acción unificada contra los enemigos comunes dentro de la fábrica.

Esto también será evidente en el caso de Mercedes Benz Argentina. Si bien allí el PRT-ERP y las organizaciones de la TRP no conformaron una lista gremial común, fueron protagonistas del conflicto sindical más importante que vivió la empresa. En octubre de 1975 los trabajadores de la planta se apostaron frente a la puerta de la oficina gremial en reclamo de aumentos salariales, elecciones sindicales libres para elegir una Comisión Interna de Reclamos (CIR) y poner fin a la intervención que venía sosteniendo la dirección nacional del SMATA hacía meses, así como en rechazo de los descuentos que esta última había dispuesto sobre sus sueldos. Ante tal presión el interventor se vio obligado a llamar a una asamblea general en la que por unanimidad se resolvió ir a la huelga y se eligió una CIR provisoria compuesta por nueve miembros (que paso a conocerse como "el grupo de los 9") de los cuales dos pertenecían a la JTP (Esteban Reimer y Víctor Hugo Ventura) y uno al PRT-ERP (Hugo Crosatto). El conflicto se extendió por veintidós días, durante los cuales se desarrollaron masivas asambleas en la puerta de la fábrica, se consiguió que los comerciantes de la zona suspendieran sus actividades en solidaridad, se logró realizar un acto en la localidad de Cañuelas, se organizaron grupos de autodefensa y un importante fondo de huelga. Todas estas actividades estuvieron dirigidas por un Comité de Lucha que se transformó, junto al "grupo de los 9", en la dirección del conflicto y en el cual los montoneros y los perretistas también fueron los principales animadores. En ese sentido todos los testimonios coinciden en que la relación al interior de la fábrica y en el marco del conflicto era inmejorable. Ante la pregunta sobre la relación con la JTP, Hugo Crosatto destaca: "para trabajar sindicalmente era espectacular... nosotros cuando hicimos la huelga, no te imaginas la actitud de los compañeros (...)". En el mismo sentido apunta el

\footnotetext{
${ }^{70}$ Entrevista con el autor. La Plata, Marzo 2017.

${ }^{71}$ DIPPBA, Mesa B, Carpeta 39, Legajo 33. Localidad Ensenada, Tomo II, folio 310.
} 
testimonio de Julio D’Alessandro, militante perretista y miembro de la Comisión Paritaria elegida en marzo de 1975:

Mira (...), como no dejábamos entrar las políticas de los partidos, ¡ $c o n$ los Montoneros no teníamos ningún problema! (...) El problema era cuando se empezaban a discutir las líneas políticas (...) En la clase obrera entre montos y el PRT no había diferencias, este... la diferencia estaba en el vértice y en la línea política, en los problemas de la fábrica, cuando había que hacer todo eso trabajábamos todos juntos sin ningún problema. El problema se da después del 73 a nivel de la discusión de líneas, pero como nosotros no dejábamos que se discutan las líneas dentro del gremio, porque teníamos que ponernos de acuerdo con las necesidades de los trabajadores y con llevar adelante la... queríamos recuperar el gremio y lo recuperamos nosotros. ${ }^{72}$

Como vemos nuevamente la lucha sindical aparece como el plano en el que las diferencias políticas, que se mostraban irreconciliables fuera de la fábrica, quedaban a un lado en post de la unidad. Esto mismo es rescatado por obreros militantes de la planta que provenían de otras corrientes políticas. Así, según Eduardo Fachal, militante del PB, las relaciones con Montoneros y el PRT-ERP eran fluidas y cotidianas. Como recuerda, si bien el PB no participaba del Comité de Lucha organizado por aquellas para "no quedar demasiado expuestos", él era un exiguo colaborador del boletín que publicaba este organismo gremial, manteniendo un diálogo constante con militantes perretistas y montoneros que en la práctica se traducía en intervenciones comunes ${ }^{73}$. Por otro lado, Ramón Segovia, militante del PST, también destaca los niveles de coordinación logrados en el marco de la huelga:

Ahí cada grupo hacía sus acciones políticas, políticamente con su grupo, pero en lo que era la fábrica era asamblea, frente común, frente democrático... o sea antiburocrático, y todo lo que se votaba en asamblea los dirigentes lo tenían que llevar a cabo, venga de donde venga, iy había de todo! Eso fue un acuerdo muy bueno que se saco. ${ }^{74}$

Al igual que en Propulsora Siderúrgica la resolución del conflicto estuvo ligada al secuestro de un gerente por parte de Montoneros. Sin embargo, como destacan todos los testimonios, el triunfo obrero fue posible gracias a los niveles de movilización alcanzados por las bases y la unidad que lograron las distintas organizaciones que dirigieron la lucha.

Como hemos visto en los tres conflictos, aún con sus diferencias, la lucha contra la burocracia sindical y por las reivindicaciones inmediatas fueron los ejes que permitieron una importante unidad de acción entre las organizaciones. Es necesario destacar que estos

\footnotetext{
${ }^{72}$ Entrevista con el autor, Buenos Aires, 2012

${ }^{73}$ Información proporcionada por Eduardo Fachal en entrevista con el autor, Capital Federal, Marzo 2017.

${ }^{74}$ Entrevista con el autor, Capital Federal, Marzo 2017.
} 
casos no se dieron de manera aislada, sino en el marco de un proceso, en el que creemos, la coordinación tendió a generalizarse. Esto puedo verse, por ejemplo, en la lucha de los obreros de Matarazzo de mayo de 1974: allí la JTP, junto a militantes del MSB y del PST, encabezaron una huelga con toma de fábrica y rehenes por aumentos salariales y la reincorporación de despedidos. Este conflicto, encabezado fundamentalmente por la fuerza montonera, se caracterizo por su contenido fuertemente antipactista, y al mismo tiempo, por la implacable intervención represiva del gobierno que termino deteniendo a 12 activistas.

Un hecho de peso en este proceso de acercamiento fue el apoyo de la JTP a la lista Marrón de SMATA Córdoba, lista clasista encabezada por el dirigente René Salamanca, que conducía la seccional desde 1972, y que llevaba en su seno a fuerzas como el PCR, VC, PO, el PC y el PRT-ERP ${ }^{75}$. El apoyo no solo se materializó en declaraciones públicas y votos, sino con guardias armadas que, junto a militantes del PRT-ERP, garantizaron la seguridad de la sede de SMATA ${ }^{76}$. Por otro lado, la unidad de acción se volvió a demostrar ante el intento de cierre de las plantas cordobesas Santa Isabel e Ilasa de la empresa IKARenault: esta lucha no solo contó con la participación de la JTP junto a las organizaciones de izquierda, sino también con la participación del propio Firmenich como orador, junto a René Salamanca y Agustín Tosco, en un acto convocado por la conducción del SMATA cordobés en repudio a su intervención por la conducción nacional del gremio y con el explicito apoyo del Ministerio de Trabajo de la Nación. En su discurso el dirigente montonero enfatizó el "camino de la unidad" como el único camino posible para dar el "combate final". ${ }^{77} \mathrm{El}$ conflicto de los mecánicos cordobeses había adquirido significancia política nacional por tratarse de un capítulo importante de la cruzada gubernamental contra las corrientes combativas del movimiento obrero. La participación de Montoneros en la defensa de un sindicato clasista "conducido por un militante no peronista" era una contundente demostración de su disposición a enfrentar abiertamente al gobierno ${ }^{78}$. Esta intervención fue recibida con entusiasmo por el PRT-ERP que saludó inmediatamente el sentido unitario de la participación montonera en el acto. ${ }^{79}$

Este proceso se profundizó, como dijimos, luego de la muerte del viejo líder cuando Montoneros inicia una confrontación abierta con el gobierno peronista. De este modo, aumentaron considerablemente la cantidad de listas gremiales antiburocráticas de unidad en las que confluían organizaciones marxistas y peronistas. Así, el 14 de septiembre de ese año se realizó el "Plenario Nacional de Sindicatos, Comisiones Internas, Cuerpos de Delegados y Comités de Lucha de gremios en conflicto" en la provincia de Tucumán en el que, a diferencia del realizado en Villa Constitución, contó con la participación activa de la JTP.

\footnotetext{
${ }^{75}$ Francisco Yofré, delegado de la JTP regional Cordoba justificaba de esta forma el apoyo a la lista marrón: "El triunfo de la Marrón se explica, en términos generales, porque representa los intereses gremiales del conjunto de los trabajadores, y por su contenido antiburocrático y de democracia sindical (...) Al no haber una expresión del peronismo revolucionario conformada en una lista, nosotros consideramos que, en función de los intereses del conjunto, la opción era clara. Las otras listas no garantizaban nada: la Gris, porque es totalmente de derecha, y la Anaranjada, porque no tiene una base ideológica firme." ("Porque apoyamos a la Lista Marron en las elecciones del SMATA" en El Peronista Nro. 5. Martes 21 de mayo de 1974.)

${ }^{76}$ Caviasca, op. cit, 230.

${ }^{77}$ Causa Peronista Nro. 6 Martes 13 de Agosto de 1974

${ }^{78}$ Evita Montonera Nro. 2 Enero-Febrero 1975

${ }^{79}$ El Combatiente Nro.130. Miércoles 14 de agosto de 1974
} 
La coordinación y acción conjunta a nivel gremial se fue generalizando en diferentes planos, desde la disputa de comisiones internas y cuerpos de delegados hasta de seccionales sindicales. Experiencias como la "Lista Gris" que intentó disputar la seccional Vicente López de la Unión Obrera Metalúrgica (UOM), en la que participaron militantes del PRTERP, la JTP, el PB, el PST, Política Obrera y Vanguardia Comunista (VC), se replicaron en diferentes zonas del país. Así, por ejemplo, en Rigolleau, una fábrica de vidrios de la localidad de Berazategui, a fines de 1974 la "Lista Naranja", compuesta por perretistas, montoneros y militantes de otras organizaciones, logró conquistar la Comisión Interna de la fábrica. Esta experiencia, que desembocó en una ardua lucha durante el año 1975, se transformó en uno de los ejemplos de la lucha antiburocrática más importantes de la Zona Sur del Gran Buenos Aires junto al de Propulsora Siderúrgica.

Por último, es de destacar que gran parte de estas experiencias terminaron confluyendo en las Coordinadoras Interfabriles del Gran Buenos Aires, que con fuerte peso de la JTP y el PRT-ERP en su dirección, fueron las protagonistas de las jornadas de Junio y Julio de 1975. Como remarca Guillermo Caviasca, “(...) todo el período en que la lucha obrera cobra protagonismo central y que tuvo como máxima expresión las coordinadoras produjo un gran acercamiento entre Montoneros y la izquierda y, especialmente el PRT, lo vio como una señal para avanzar en la unidad" $" 80$.

Sin embargo, esa unidad no fue posible y más allá de la búsqueda constante por trascender los límites de la lucha sindical, lo cierto es que fue ese el único plano en el que se alcanzaron niveles importantes de coordinación y acción conjunta. Las palabras de Luis Mattini, dirigente perretista y responsable nacional de la Mesa Sindical del PRT-ERP, en ese sentido resultan contundentes:

"En un conflicto sindical casi siempre peleábamos para el mismo lado, estábamos todos jugados en la misma y el enemigo casi siempre era el mismo. Eso es importante, el enemigo te une, y casi siempre era la burocracia sindical, o el patrón directo o la burocracia sindical (...) casi nunca había dificultades, era de buena coordinación. Las dificultades eran para pasar de ahí a otro nivel, pero dentro del conflicto o de lo que se estaba planteando adentro de la fábrica (...) teníamos una coincidencia general sobre el sindicalismo (...)"

\section{Consideraciones Finales}

En este trabajo hemos analizado la polémica que sostuvo el PRT-ERP con la TRP, fundamentalmente con FAR y Montoneros. Además, hemos indagado sobre la forma en que pretendió vincularse a estos sectores al interior de las fábricas e intentamos avanzar en el análisis de casos para observar cómo se dio efectivamente esa relación en la práctica.

\footnotetext{
${ }^{80}$ Caviasca, op. cit., 230
} 
Como vimos, el PRT-ERP partió de un análisis marxista del peronismo que pretendió alejarse del "gorilismo de izquierda" 81 , así como también del revisionismo que lo entendía como un movimiento de liberación nacional. La definición del peronismo como un fenómeno "bonapartista" le permitía explicar el carácter burgués del movimiento y de Perón como su líder, al mismo tiempo que comprender su base popular y proletaria. No dejando de reconocer que se trataba de una primera etapa de la conciencia de la clase obrera, sin embargo, era concebido como una traba que debía ser superada para transitar el camino hacia el socialismo y un arma poderosa con la que contaban las clases dominantes para frenar la lucha revolucionaria. Desde estas claves interpretó el retorno de Perón como una estrategia contrarrevolucionaria de las clases dominantes que consistía, sobre todo, en introducir una "cuña" entre las organizaciones revolucionarias marxistas y peronistas. Con esta certeza se propuso agudizar las contradicciones del peronismo revolucionario polemizando con sus organizaciones para tratar de traccionarlas a "posiciones revolucionarias". Combatir las "desviaciones reformistas y populistas" en el seno de la clase obrera y garantizar "la unidad de los revolucionarios" eran partes de esa misma tarea. Sin embargo, mas allá de esos esfuerzos y de los incesantes llamados a la unidad, esta última no fue posible, en parte, debido a las diferencias profundas que cada una de las organizaciones tenía en la forma de entender el carácter que debía asumir la revolución en nuestro país. Esto se veía reflejado, en gran medida, en el tipo de relación que cada una entablaba con el peronismo.

Ahora bien, como hemos intentado demostrar, la unidad tendió a darse generalmente en el plano de la lucha antiburocrática en el que más allá de los matices y las tensiones, había grandes coincidencias. La existencia de un enemigo común (la burocracia), la apuesta de construir democracia sindical a través de los espacios de base y el papel que le asignaban cada una de las organizaciones a la clase obrera en sus proyectos revolucionarios, fueron elementos centrales para la construcción de una experiencia común al interior de la fábrica, en la que los problemas concretos y las exigencias de la práctica cotidiana hacían posible y hasta "natural" la "unidad en la acción". Como vimos en los ejemplos trabajados los militantes fabriles tendieron a dejar a un costado las diferencias que aparecían en "el vértice" de sus organizaciones e incluso, a veces, dieron debates con sus propias direcciones para salvaguardar las experiencias unitarias que habían logrado construir. Resulta interesante observar que allí, como en Villa Constitución, cuando los conflictos tendieron a trascender los límites de la fábrica y se tornaron una cuestión de la política nacional las tensiones crecieron y las diferencias políticas cobraron mayor dimensión, llevando incluso a poner en riesgo la unidad, mientras que en los conflictos que no adquirieron tal relevancia las organizaciones tendieron a confluir sin mayor problema.

En ese sentido consideramos que la unidad, al menos en aquella etapa, estuvo motorizada fundamentalmente por la militancia fabril que, al calor de la lucha antiburocrática, materializaron aquello que no pudo concretarse por fuera de los muros de las fábricas. Entendemos que dicha hipótesis deja planteada la necesidad de avanzar en la investigación de tales articulaciones en casos no estudiados. Al mismo tiempo advierte la

${ }^{81}$ De Santis, op. cit., 127 
necesidad de abordar de manera sistemática el estudio de las relaciones entre las organizaciones de la nueva izquierda al interior de las fábricas.

\section{Bibliografía}

- Andrea Andujar y Agustín Santella, El Perón de la fábrica eramos nosotros. Luchas metalúrgicas de Villa Constitución 1970-1976., Buenos Aires, 1e ed, Desde el Subte, 2007.

- Pablo Bonavena, Mariana Maañon, Gloria Morelli, Fabián Nievas, Roberto Piva y Martín Pascual, Orígenes y Desarrollo de la Guerra Civil en la Argentina. 1966-1976., Buenos Aires, Eudeba, 1998.

- Brennan, El Cordobazo: guerras obreras en Córdoba, 1955-1976. Bs. As., Editorial Sudamericana, 1996.

- Luis Brunetto, 14250 o paro nacional. Bases obreras, direcciones sindicales peronismo en la crisis del Rodrigazo: junio y julio de 1975., Buenos Aires, Estación Finlandia, 2007.

- Esteban Campos, "La cuestión del peronismo en el debate entre las FAR y el PRT-ERP”, Anuario Nro. 25, Escuela de Historia Revista Digital Nro.4, FHumyAr, 2013.

- Esteban Campos, "Marxismo, ideología y experiencia en el debate entre las FAR y el PRTERP" Unité Mixte de Recherche Mondes américains; Nuevo Mundo Mundos Nuevos; 2013; 12-2013; 1-20

- Mariano Casco Peebles y María Agustina Lenuda, "Conflicto obrero y acción guerrillera. La huelga en Mercedes Benz en 1975 y el secuestro de un nazi.” En: Archivos, año V, nro 9, septiembre de 2016, 97-116.

- Guillermo Caviasca, Dos caminos. ERP-Montoneros en los setenta., Argentina Ediciones del CCC, 2006.

- Daniel De Santis, A vencer o morir. Historia del PRT-ERP: documentos. Tomo 1 Volumen 1, Buenos Aires, Nuestra América, 2004.

- Daniel De Santis, A vencer o morir. Historia del PRT-ERP: documentos. Tomol Volumen 2, Buenos Aires, Nuestra América, 2006.

- De Santis, Daniel: A vencer o morir. PRT-ERP. Documentos, Tomo II, Buenos Aires Eudeba, 2000.

- Daniel De Santis, La historia del PRT-ERP por sus protagonistas, Buenos Aires, A formar filas editora guevarista, 2010.

- Rafael Farace y Gabriela Jäkel, "Nociones sobre 'democracia obrera' y "burocracia sindical" en la izquierda de los años 70. Una comparación entre la izquierda peronista y la izquierda marxista", Trabajo y sociedad Nro 26, Santiago del Estero, 2016.

- Mora González Canosa, Las Fuerzas Armadas Revolucionarias: Orígenes y desarrollo de una particular conjunción entre marxismo, peronismo y lucha armada (1960-1973), FaHCE-UNLP, Tesis de posgrado, 2012.

- Ianina Harari, "La burocracia peronista. El sindicato automotriz argentino ante el auge de la lucha de clases. 1969-1976” En: Revista IZQUIERDAS, año 3, número 8, 2010.

- Daniel James, Resistencia e Integración. El peronismo y la clase trabajadora argentina 1946-1976, Buenos Aires, Editorial Sudamericana, 1990.

- Sebastián Leiva Flores, "Teoría y práctica del poder popular, los casos del MIR, Chile, 1970-1973 y el PRT-ERP, Argentina, 1973-1976", Santiago de Chile, Universidad de Santiago de Chile, 2007. 
- Héctor Löbbe, La guerrilla Fabril. Clase obrera e izquierda en la Coordinadora de Zona Norte del Gran Buenos Aires (1975-1976), Buenos Aires, Ediciones ryr, 2006.

- Federico Lorenz, Algo parecido a la felicidad. Una historia de la lucha de la clase trabajadora durante la década del setenta (1973-1978), Buenos Aires, Edhasa, 2013.

- Marín Mangiantini, El trotskismo y el debate en torno a la lucha armada. Moreno, Santucho y la ruptura del PRT, Buenos Aires, Topo Blindado, 2014

- Luis Mattini, Hombres y mujeres del PRT-ERP de Tucumán a la Tablada, La Plata, De la Campana, $4^{\circ}$ Edición, 2003.

- Julieta Pacheco, "Análisis de la militancia sindical de Montoneros: La Juventud Trabajadora Peronista y sus luchas", e-1@ tina, Vol. 13, num. 50, 2015.

- Julieta Pacheco, "La izquierda peronista y su inserción en el movimiento obrero", Revista Latino-americana de estudios do trabalho Nro. 19, año 19, 2014, 157-184.

- Mariel Esper Payo, "El Frente Antiimperialista y por el Socialismo, más que un 'ejercito político' impulsado por el PRT-ERP”, Questión, vol.1, nro 29, UNLP

- Pablo Pozzi, Por las sendas argentinas... El PRT-ERP. La guerrilla Marxista, Buenos Aires, Eudeba, 2001.

- Pablo Pozzi, y Alejandro Schneider, Los setentistas. Izquierda y clase obrera: 1969-1976. Bs. As, Eudeba, 2000.

- Florencia Rodríguez "Conciencia de clase y política. El caso de los obreros de Propulsora Siderúrgica. 1973-1975”, En: PYMSA, Documentos y Comunicaciones, 2010

- Santiago Stavale "¿Amplio frente sindical o brazo sindical perretista? Reconstruyendo la trayectoria del Movimiento Sindical de Base", VIII Jornadas de Sociología, FaHCE-UNLP, 2014.

- Santiago Stavale y Daniel De Santis, Un partido de la clase obrera. La política del PRTERP en el movimiento obrero, Ciudad Autónoma de Buenos Aires, Ediciones Finlandia, Colección A formar Filas, 2016.

- Juan Carlos Torre, El gigante invertebrado. Los sindicatos en el gobierno 1973- 1976, Buenos Aires, Siglo XXI, 2004.

- María Cristina Tortti, "La nueva izquierda argentina. La cuestión del peronismo y el tema de la revolución.", María Cristina Tortti (Directora), Mauricio Chama y Adrián Celentano (co-directores), La nueva izquierda argentina (1955-1976): socialismo, peronismo y revolución., Rosario, Prehistoria Ediciones, 2014.

- Felipe Venero, "La izquierda y los trabajadores en Propulsora Siderúrgica durante el tercer peronismo 1973-1976" Jornadas Académicas de la Facultad de Humanidades y Ciencias de la Educación, Universidad de la República, Montevideo, 2015

- Horacio Verbitsky, Ezeiza, Buenos Aires, Editorial Contrapunto, 1985.

- Eduardo Weisz, Claves para una interpretación de su singularidad. Marxismo, Internacionalismo y Clasismo., Buenos Aires, Ediciones del CCC, 2006.

- Ruth Werner y Facundo Aguirre, Insurgencia obrera en la Argentina. 1969-1976. Clasismo, coordinadoras interfabriles y estrategias de la izquierda, Buenos Aires, Ediciones IPS, 2007.

- Jorge Winter, La clase trabajadora de Villa Constitución. Subjetividad, estrategias de resistencia y organización sindical, Reunir, Buenos Aires, 2010

- Mariano Zarowsky, "Reforma y revolución: la vía chilena al socialismo en la nueva izquierda intelectual argentina", Izquierdas, 29:133-148, septiembre 2016

Fuentes: 
- Cristianismo y Revolución Nro. 28. Abril de 1971

- Causa Peronista Nro. 6

- El Combatiente Nros. 76, 81, 89, 92, 101, 102, 105, 113, 114, 125, 130 y 134.

- El Descamisado Nros. 4, 37 y 44.

- El Peronista Nro. 5.

- Evita Montonera Nro. 2

- Liberación Nros. 1 y 4.

- La Justa. Órgano de la JTP. Nro. 2 de Junio de 1974

- Militancia Peronista para la Liberación Nros. 32 y 37.

- Movimiento Nro.3

- DIPPBA, Mesa B, Carpeta 39, Legajo 33. Localidad Ensenada, Tomo I y II 